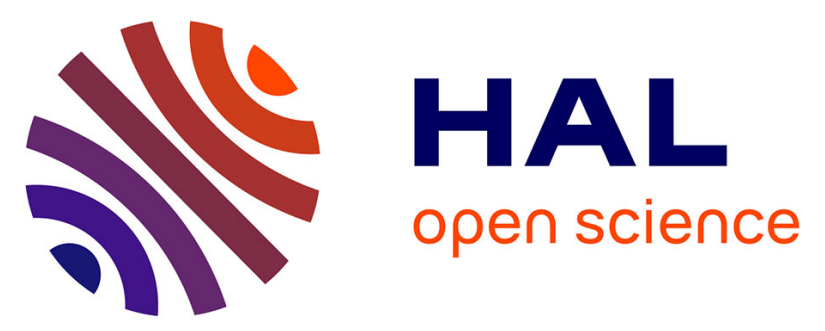

\title{
Using ground penetrating radar to understand the failure of the Koh Ker Reservoir, Northern Cambodia
}

Ian Moffat, Sarah Klassen, Tiago Attorre, Damian Evans, Terry Lustig, Leaksmy Kong

\section{- To cite this version:}

Ian Moffat, Sarah Klassen, Tiago Attorre, Damian Evans, Terry Lustig, et al.. Using ground penetrating radar to understand the failure of the Koh Ker Reservoir, Northern Cambodia. Geoarchaeology: An International Journal, 2019, 10.1002/gea.21757 . hal-02274854

\section{HAL Id: hal-02274854 \\ https://hal.science/hal-02274854}

Submitted on 30 Aug 2019

HAL is a multi-disciplinary open access archive for the deposit and dissemination of scientific research documents, whether they are published or not. The documents may come from teaching and research institutions in France or abroad, or from public or private research centers.
L'archive ouverte pluridisciplinaire HAL, est destinée au dépôt et à la diffusion de documents scientifiques de niveau recherche, publiés ou non, émanant des établissements d'enseignement et de recherche français ou étrangers, des laboratoires publics ou privés. 
This is the peer reviewed version of the following article:

Moffat I, Klassen S, Attorre T, Evans D, Lustig T, Kong L. Using Ground Penetrating Radar to Understand the Failure of the Koh Ker Reservoir, Northern Cambodia. Geoarchaeology. 2019. 1-9

which has been published in final form at https://doi.org/10.1002/gea.21757. This article may be used for non-commercial purposes in accordance with Wiley Terms and Conditions for Use of SelfArchived Versions.

\title{
Using ground penetrating radar to understand the failure of the Koh Ker Reservoir, Northern Cambodia
}

Ian Moffat ${ }^{* 1,2}$, Sarah Klassen ${ }^{3}$, Tiago Attorre ${ }^{1}$, Damian Evans ${ }^{4}$, Terry Lustig ${ }^{5}$, Leaksmy Kong ${ }^{4}$

\begin{abstract}
Ground penetrating radar, probing, and excavation were used to create a contour map of the topography of a buried laterite pavement forming the spillway of a large abandoned reservoir at the Angkorian-period city of Koh Ker in Cambodia. Calculations of the flow velocity of water through the spillway, based on the topography of the laterite surface, demonstrate that this outlet was even less adequate for passing the flow of water from the Stung Rongea catchment than had been estimated previously by Lustig, Klassen, Evans, French, \& Moffat (2018). We argue that this design flaw contributed substantially to the failure of the reservoir's dike, possibly during the first rainy season after construction, which may have contributed to Koh Ker's remarkably short-lived tenure as the political center of the Khmer Empire.
\end{abstract}

\section{Keywords}

Cambodia, ground penetrating radar, Koh Ker

${ }^{1}$ Archaeology, College of Humanities, Arts and Social Sciences, Flinders University, Bedford Park, Australia

${ }^{2}$ McDonald Institute for Archaeological Research, University of Cambridge, Cambridge, UK

${ }^{3}$ Anthropology Department, University of British Columbia, Vancouver, British Columbia, Canada

${ }^{4}$ École française d'Extrême-Orient, Paris, France

${ }^{5}$ Independent Scholar, Sydney, Australia

*Corresponding author: Archaeology, College of Humanities, Arts and Social Sciences, Flinders University, Bedford Park, GPO Box 2100, Adelaide 5001, South Australia. Email: ian.moffat@flinders.edu.au 


\section{Introduction}

The Khmer Empire dominated mainland Southeast Asia for approximately 6 centuries (9th to 15th centuries CE (Common Era)). For most of this period, the Empire was ruled from a capital at Angkor, Cambodia. Much research has been done regarding the water management system of Angkor and its implications for the resilience and sustainability of the center (Buckley et al., 2010; Diamond, 2009; Lustig, 2012). These studies have highlighted the importance of effective water management systems to mitigate the seasonality of the monsoon, attenuate fluctuations in water supply, and ensure consistent yields of rice in the face of long-term hydroclimatic instability. The breakdown of those hydraulic systems has been implicated in the collapse of the Khmer Empire in the 14th to 15th century CE (Lucero, Fletcher, \& Coningham, 2015).

Much less research has been focused on hydraulic systems elsewhere in the Khmer Empire. The monumental complex of Koh Ker, located $\sim 90 \mathrm{~km}$ northeast of Angkor, remains relatively poorly understood even though it was briefly the capital in the middle of the 10th century CE under King Jayavarman IV, the only capital throughout six centuries of the Khmer Empire to be established outside of the Angkor region. The site is located in an area of gently sloping hills and stone outcrops, far removed from the low-lying floodplains that define the Khmer heartland (Evans, 2013). Koh Ker is well-known for its monumental architecture (most of which ostensibly belongs to the short period from 928 to 944 CE in which it was mainland Southeast Asia's pre-eminent locus of power) and for its impressive tradition of massive sandstone statuary (Bourdonneau, 2011). The site has a collection of inscriptions that have been used to trace the outlines of its history and we know from these texts that its name was Lingapura or the city of the linga, so named for the Śiva-linga that crowned the stepped pyramid at its center (Parmentier, 1939).

Because of its remoteness, Koh Ker has largely escaped the attention of archaeologists, leaving Parmentier's (1939) interpretations of the site, based principally on a survey of monuments and inscriptions, relatively unchallenged until recently. This has led to the widespread interpretation that Koh Ker is located in a harsh and inhospitable environment, that subsistence there was precarious and vulnerable to drought, and that it was an ephemeral city with only modest achievements in water engineering compared with Angkor (Evans, 2013). Recently, however, new evidence from remote sensing and paleobotany has revealed a long and complex history of occupation. Wide area lidar mapping in 2012 revealed that anthropogenic modification associated with Koh Ker covers an area of more than $67 \mathrm{~km} 2$ and includes habitation areas as well as local shrines and other elements of an urban complex stretching between and beyond the well-known temples at the monumental core (Evans, 2013; Evans et al., 2013). Relict rice field patterns and traces of numerous weirs have also been identified in the lidar data, revealing a significant investment in the management of water (Evans, 2013; Evans, Hanus, \& Fletcher, 2015). Given the undulating topography of Koh Ker, the retention of run-off-in particular the harnessing of the seasonal watercourses such as the Stung Rongea River immediately north of Koh Ker-was clearly a significant concern for engineers. Paleoecological studies and radiocarbon dates show that intensive management of the landscape began as early as the 7th century CE, and continued until a period of apparent abandonment in the 15th century CE (Hall, Denny, \& Hamilton, 2018). This mirrors recent results from Angkor which also suggest a longer and more complex period of decline of that capital (Penny, Hall, Evans, \& Polkinghorne, 2019).

Overall, there is evidence for intensive and extensive reengineering of the landscape spanning almost a millennium at the so-called "ephemeral capital" of Koh Ker, which clearly has a much more complex and interesting history than previously assumed. Moreover, because that history spans the entire period from the pre-Angkor era through to the decline of the Khmer Empire in the 15th century CE, 
understanding what happened at Koh Ker becomes highly consequential for understanding the historical trajectory of the Empire, and more broadly, of urbanism in mainland Southeast Asia.

Many of the key questions that arise in relation to Koh Ker are related to water management: was there a major investment in massive, state-sponsored hydraulic infrastructure, as at Angkor? Was the system problematic, and was its eventual failure a cause or a consequence of Koh Ker's depopulation and abandonment? Was Koh Ker's history shaped by an infrastructural collapse at Angkor, which precipitated a "diaspora" away from the region, or is the history of the site better explained by more localized factors?

New evidence shows that water engineering projects completed at Koh Ker rivaled those of Angkor in scale and ambition. During its period as the center of the Empire, a $7 \mathrm{~km}$ long embankment was built to the north of the city of Koh Ker. The embankment formed a causeway into the city and a water retention feature in the form of a dike that retained the seasonal flow of the Stung Rongea River (Evans, 2013, p. 109-112). This was a significant landscape feature, as it was the longest water management feature across a river valley in Khmer history, and created the largest artificial reservoir that we know of so far in the Angkor period (Lustig, et al., 2018). Recent studies suggest that this feature failed by overtopping within a few years of construction (Lustig et al., 2018). This may have been a major factor in the relocation of the capital of the Khmer Empire back to Angkor. In this paper, we examine one of the two water outlets within the dike, the northern chute (Figure 1), in detail, to understand better why the embankment overtopped. The chute is an artificial water channel, rectangular in plan, $40 \mathrm{~m}$ wide and $230 \mathrm{~m}$ long with $4 \mathrm{~m}$ high walls along the side. Near the upstream end, there are the remains of a laterite spillway that appears to have been subsequently repurposed to form a causeway. Using excavation, probing, a digital surface model (DSM) derived from airborne lidar data (Evans et al., 2013), and a map of the buried laterite surface derived from ground penetrating radar (GPR), we estimate the chute's discharge capacities before and after failure. We then refine earlier estimates of the short period between construction and when the dike failed through overtopping. The other water outlet, the southern spillway, is discussed in detail in Lustig et al. (2018).

Spillways are a common feature in reservoir design, serving to transfer excess water over the crest of the water-retaining structure or dike in a controlled fashion. This ensures that the water contained in the reservoir does not overtop the water-retaining structure during flood periods. Chute spillways such as the one at Koh Ker are constructed as a discrete channel that contains the water as it travels down the slope over the dike. Spillways always require some form of protection at their downstream end to prevent erosion by water flow. The spillway design should be sufficient to discharge large, rare flows of the rivers draining into the reservoir otherwise overtopping of the reservoir wall is inevitable. The slope and size of the chute helps predict maximum flow velocity and so mapping its topography is a means of modeling if the design of the reservoir was adequate. If the spillway is washed away its profile is changed and modeling allows the calculation of postfailure flow velocity.

Geophysical survey has rarely been used for archaeological investigations in Cambodia, with the principal focus of published studies being the mapping of large-scale monumental structures (Sonnemann, 2015; Sonnemann, O'Reilly, Chhay, Pottier, \& Fletcher, 2015) or pottery kilns (Sonnemann \& Chhay, 2014). Nonetheless, this approach has great potential to contribute to archaeological studies in the region because of its ability to provide rapid, noninvasive assessments of the subsurface over large areas (e.g., Donati et al., 2017). GPR is a commonly applied geophysical method that works by transmitting radar energy into the subsurface and measuring the timing and amplitude of reflections from boundaries in dielectric permittivity (Conyers, 2013). This method has been widely used in archaeological research (Conyers, 2012, 2013, 2016) and has demonstrated its 
utility in bedrock mapping for archaeological (David et al., 2017a; David et al., 2017b) and geological applications (Mellett, 1995).
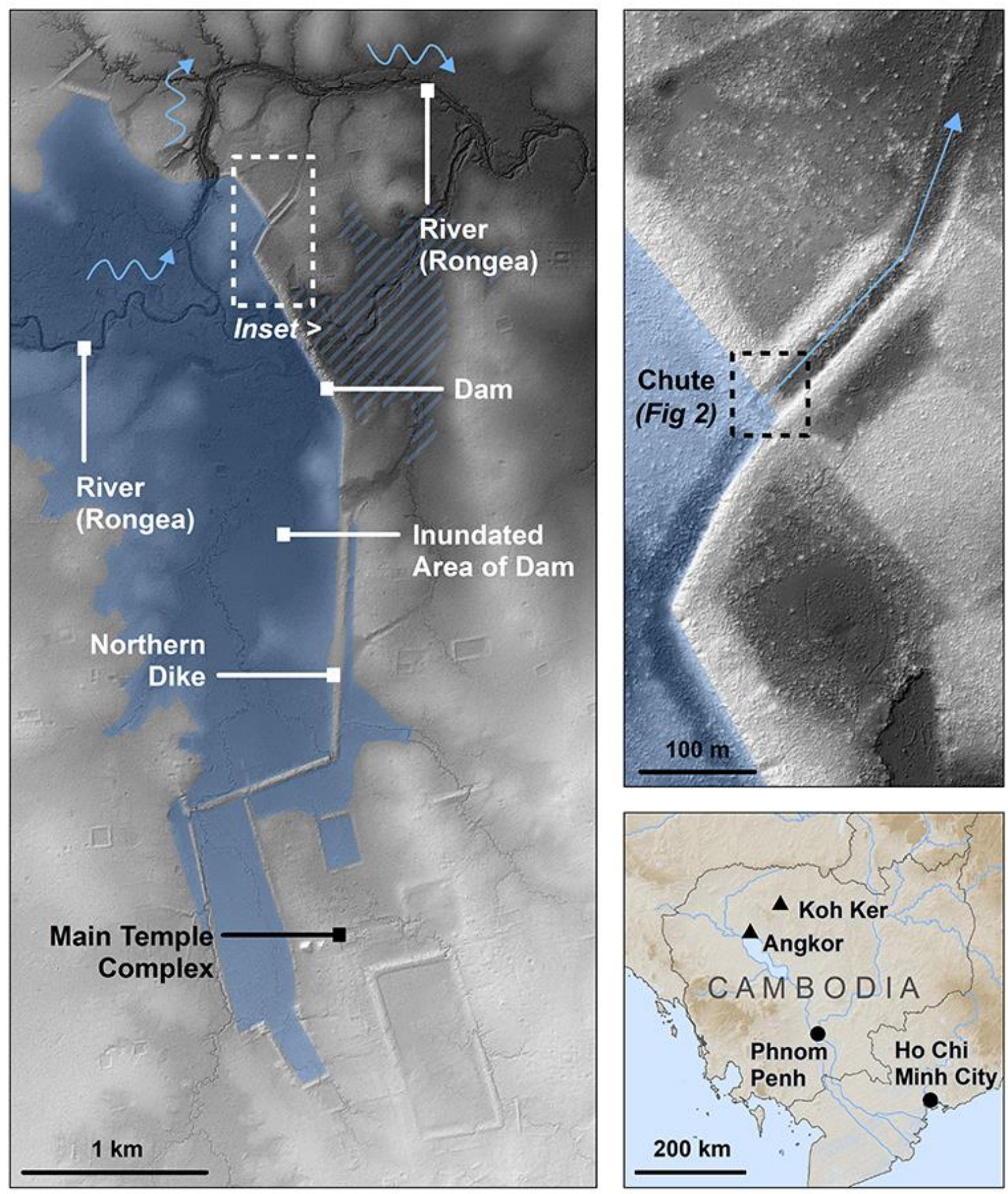

Figure 1. Regional map of Koh Ker showing the location of the chute and key archaeological features. The detailed map area (top right) is shown as a white dashed box on the regional map (left). The black dashed line in the detailed map area shows the approximate area of Fig 2. The location of Koh Ker compared with Angkor, Phnom Penh, and Ho Chi Minh City is shown in the bottom right. North is up in all figures. 


\section{Methods}

The field investigations for this project focused on mapping of the, largely buried, laterite blocks forming the chute spillway via excavation, probing and using the GPR to create a detailed DSM of this surface. The study area is within the chute and can be divided into two broad features, partly visible on the surface (Figure 2). Feature $A$ is a rectilinear laterite structure upstream (i.e., SW) of the original crest of the spillway interpreted to be a causeway built after the dike was no longer in use. Feature $B$ contains most of the laterite spillway from just upstream of the crest, with a level of $68.5 \mathrm{~m}$ above sea level (ASL) (Lustig et al., 2018, p. 203), and nearly to the end of the downstream face.

Investigations at the chute at Koh Ker were preceded by clearing the entire area of vegetation and having the Cambodian Mine Action Centre (CMAC) survey the area with a metal detector to check the area as being clear of unexploded ordnance.

Aerial imagery collected using a DJI Phantom 4 UAV was used to create a DSM and georectified orthophoto using Agisoft Photoscan Professional software. The GPR data were processed with reference to a local grid and georeferenced to the lidar DTM using features surveyed with the total station (Evans et al., 2013).

Four trenches were excavated at the chute to determine the form of laterite features within the area (see Figure 2). Excavations proceeded by arbitrary levels (spits). As this was a water management feature, very few artifacts were expected or found. Excavation trench 1 revealed a very flat pavement of laterite blocks in the eastern corner, overlain by blocks associated with the causeway (Feature A). Excavation trench 2 revealed laterite blocks in a variety of configurations including as a flat pavement, in an en echelon formation, and as apparently eroded loose blocks. Excavation trench 3 located no laterite to a total depth of approximately $1.5 \mathrm{~m}$; however, subsequent probing reached laterite between a total depth of $1.7-2.7 \mathrm{~m}$ in the NE half of the trench. Excavation trench 4 encountered laterite in most areas of the trench at depths between 1 and $1.7 \mathrm{~m}$ that did not form a pavement and had no consistent pattern or orientation, so we expect that these blocks are not in situ. Overall, the excavations showed the laterite surface to be topographically complex and to reflect a number of construction, excavation and erosion events.

Since it was not feasible to excavate the entire site, the area between excavation units was probed using a metal rod to determine the depths to laterite. The locations and elevations of the laterite as revealed by the probe were surveyed with a total station. The depths to laterite varied from 0 to $>1.8 \mathrm{~m}$ (which was the maximum length of the probe).

The GPR survey was undertaken after the excavation and probing surveys had revealed that the laterite surface was extremely uneven. We used GPR to create a high-resolution contour map of the topography of the buried laterite blocks in the downstream portion of the chute spillway, which would have been prohibitively expensive and excessively invasive to undertake via conventional excavation.

GPR data were collected in a $20 \mathrm{~m} \times 42 \mathrm{~m}$ grid of $1 \mathrm{~m}$ spaced parallel lines located on the northeast side of the causeway (Figure 2). The grid had a very uneven topography, with many laterite blocks exposed at the surface. GPR data were collected using a Malå X3M GPR with a $500 \mathrm{Mhz}$ antenna. Data acquisition settings included a sampling frequency of $9,820 \mathrm{Mhz}, 1,024$ samples, 2 stacks, 423 traces, and a trace interval of $1 \mathrm{~cm}$. Data were processed and interpreted in GPR Slice using a sequence that corrected for timezero, applied low and high pass filters, adjusted the gain, undertook a migration, and applied a Hilbert transform. After hyperbola fitting (Cassidy, 2009, p. 159) the relative dielectric permittivity was estimated as 17.85 for the study area. GPR penetration is drastically reduced after $\sim 45 \mathrm{~ns}$ (or $\sim 1.5 \mathrm{~m}$ ) due to signal attenuation which we attribute to the clay-rich soil in the area, with 
only a few deep geological features discernible in the reflection profiles. The GPR profiles were interpreted to give the depth to the first major reflector along each line, which we believe to be the laterite layer based on probing and excavating. The picks were gridded to create a contour of depth below the surface in ArcGIS using the inverse distance weighted interpolation function. These data were topographically corrected with reference to the DSM created from the photogrammetry data to create a contour map of the laterite surface in meters ASL, shown in Figure 2 . In addition to the interpretation of GPR profiles, these data were combined into a pseudo-3D cube, and 41 amplitude slice maps with a thickness of $5 \mathrm{~ns}$ ( $\sim 16 \mathrm{~cm}$; Conyers, 2013, Goodman, Nishimura, \& Rogers, 1995) were created to help understand the subsurface geomorphology of the site.

\section{Results}

The contour plot of the elevation of the laterite surface revealed a number of areas of interest, which are shown in Figure 2. Area $A$ is equal to or more elevated (68.5-69.2m ASL) than the crest of the spillway. We suggest that this section of the chute was not eroded and may have been built up by surplus laterite blocks excavated from Area B after the failure of the reservoir. These blocks may have been stored in anticipation of being used to build the causeway but ultimately not needed.

In Area B the laterite surface decreases in elevation relatively quickly downstream from Area $A$. We interpret the increased depth to the laterite surface in Area B to reflect the anthropogenic removal of laterite blocks for construction of the western part of the causeway, probably after the initial failure of the dike rather than erosion of blocks by water flow (Lustig et al., 2018, p. 203). Our interpretation is based on the regular rectangular form of the area where laterite blocks are missing, which is far more suggestive of human excavation than fluvial erosion.

In Area C the laterite surface begins at $68.4 \mathrm{~m}$ ASL (just below the interpreted elevation of the crest of the spillway) and decreases gradually downstream to an elevation of $66.4 \mathrm{~m} \mathrm{ASL}$, displaying a convex form on the crest. This conforms with good hydraulic design principles (Chanson, 2004, p. 391-430) and we interpret this to represent the original form of the spillway before erosion or the removal of blocks for the subsequent construction of the causeway.

Area $D$ seems to have been the main zone of erosion of the spillway, based on the lower elevation of the laterite surface in this region (67.9-66.5m ASL). It is possible that these blocks were removed by hand to build the causeway. However, since the blocks have been predominantly removed distal to the causeway, our interpretation is that these blocks were eroded by fast-flowing water. This mirrors the more extreme damage that has been documented at the other spillway, some $2 \mathrm{~km}$ from our site (Evans, 2013; Lustig et al., 2018). While we have not attempted to model the erosion of the spillway in a detailed way, transport of laterite blocks of this size is possible given the calculations outlined below (Clarke, 1996, p. 174).

As expected from our excavation results, the pavement is particularly deep and uneven in Area E. The location and form of this feature support the idea that laterite blocks were excavated from the eastern side of the spillway and stored at the easternmost end for use in the construction of the causeway.

Based on our assumption that the profile of Area $C$ represents the original design of the chute, and Area $D$ the postfailure profile, these areas were used to calculate flow using the standard discharge formula for weirs (e.g., USACE, 1992, Plate 3-3) namely,

$$
Q=C_{D} L H^{1.5}
$$


where $Q$ is the flow, $C_{D}$ is the coefficient of discharge, $L$ is the length of the crest of the spillway, and $H$ is the total head of the water upstream. The coefficient of discharge was estimated using the graphs of the U.S. Army Corps of Engineers for various spillway parameters and reservoir heights (USACE, 1992, Plates 3-2 \& 3-3). The coefficients of discharge for the eroded spillway were estimated assuming that the critical depth of flow was at the crest across the width of the spillway. The $C_{D}$ was estimated for the eroded spillway for each section where the elevation of the crest was within a $0.1 \mathrm{~m}$ contour interval, and the flows were calculated and then summed in accordance with the numerical integration procedure suggested by Horton (1907, p. 56).

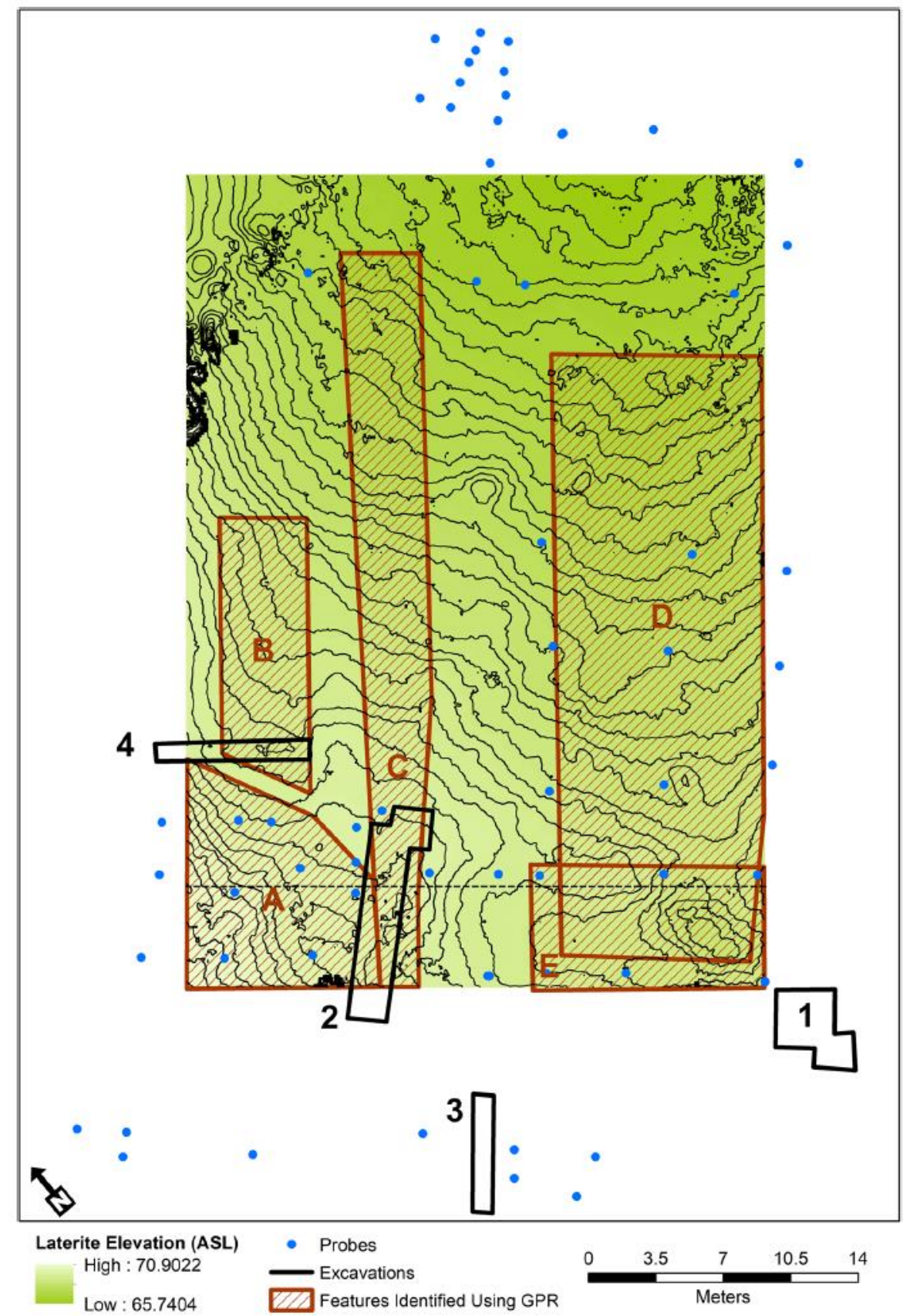

Figure 2. Detailed map of the study area showing probe and excavation locations and the elevation of the laterite blocks as interpreted from the GPR data. Features discerned from laterite DSM are: (A) possible pile of unused excavated laterite blocks; (B) area excavated for laterite blocks for constructing the northwestern part of the causeway; $(C)$ section of spillway face suffering minimal erosion; (D) section of spillway face possibly suffering maximum erosion; (E) area excavated for laterite blocks for constructing southeastern part of the causeway. DSM, digital surface model; GPR, ground penetrating radar. 
The estimated flow in the chute with the reservoir level at 70m ASL-which we think the water level in the reservoir reached but did not exceed (Lustig et al., 2018, p. 203)-was revealed by our calculations to be $70 \mathrm{~m}^{3} / \mathrm{s}$ in its original form and $\sim 90 \mathrm{~m}^{3} / \mathrm{s}$ with the laterite blocks removed by erosion. We compared this rate of discharge with the modelled rainfall in the Stung Rongea River catchment for the period 1980-2007 (DIAS, 2010), which demonstrated that, even in combination with the discharge from the southern spillway, the capacity for draining excess water from the reservoir was quite inadequate (Lustig et al., 2018, p. 205) and overtopping leading to rapid failure of the embankment was inevitable. We calculate that were the Koh Ker hydraulic system in place from 1980 to 2007, it would have overtopped at least once every year and more than once during 21 of those years. This is consistent with what appear to be unfinished works to raise the level of the $7 \mathrm{~km}$ long embankment by at least a meter (Lustig et al., 2018, p. 200). Lustig et al. (2018) postulate that these works were initiated following a first overtopping event. In addition to providing useful information about the depth to laterite, GPR data from beneath the laterite surface (shown as (b) and (c) in Figure 3) reveal a number of geometric shapes that are difficult to explain in the context of the spillway construction. These features, which have not been excavated, are most likely anthropogenic based on their sharp edges. They are made up of higher amplitude reflectors, with the material in between showing high levels of signal attenuation. We tentatively interpret these features as being laterite block work used to infill variations in the sub-base of the sloping spillway to facilitate the laying of the laterite pavement. One of the major uncertainties in interpreting the GPR data for this project was correcting for the effect of the multiple laterite blocks on the surface of the survey grid. The GPR frequently bumped over these features leading to decoupling of the antenna from the ground surface. This effect added considerable complexity to the data interpretation as the geometry of many of the subsurface features was distorted. We have attempted to correct for this effect both by constraining our identification of the laterite surface with the probe data and by topographically correcting our picks using the high-resolution DSM generated from the aerial photographs. We believe that this approach is adequate; however, for future investigations of this kind, we would complement the GPR data with Electrical Resistivity Tomography (ERT) profiling to further validate our interpretation. ERT would be well suited for defining a soil/rock interface (e.g., Chambers, Wilkinson, Wardrop, Hameed, Hill et al., 2012) and would not be affected by the rough ground surface.

Overall, our study demonstrates that the failure of the Koh Ker dike was the result of poorly designed outlets whose total capacity was not sufficient to pass the peak annual flow of the Stung Rongea River, and a level of the crest of the embankment that was too low. This event may have had important political implications because not long after the failure of this dike, the center of the Khmer Empire returned to Angkor, where it would remain for many centuries. Unfortunately, establishing an absolute chronology for the weir failure is hindered by the episodic nature of this event and the lack of associated datable materials. However, we hope that ongoing research using other occupation proxies (Hall, Penny, \& Hamilton, 2018) will continue to refine our understanding of these events. Similarly, geophysics has largely been used in Cambodian archaeology to directly detect archaeological material (Sonnemann \& Chhay, 2014; Sonnemann et al., 2015). Where GPR has been previously used in studies of water management features (Sonnemann, 2015) it has not been used to understand the engineering aspects of design. Given the centrality of water management to Angkorian archaeology (i.e., Fletcher, Pottier, Evans, \& Kummu, 2008), we expect the use of geophysical methods to understand detailed aspects of the design of such features to have considerable application in the future. 

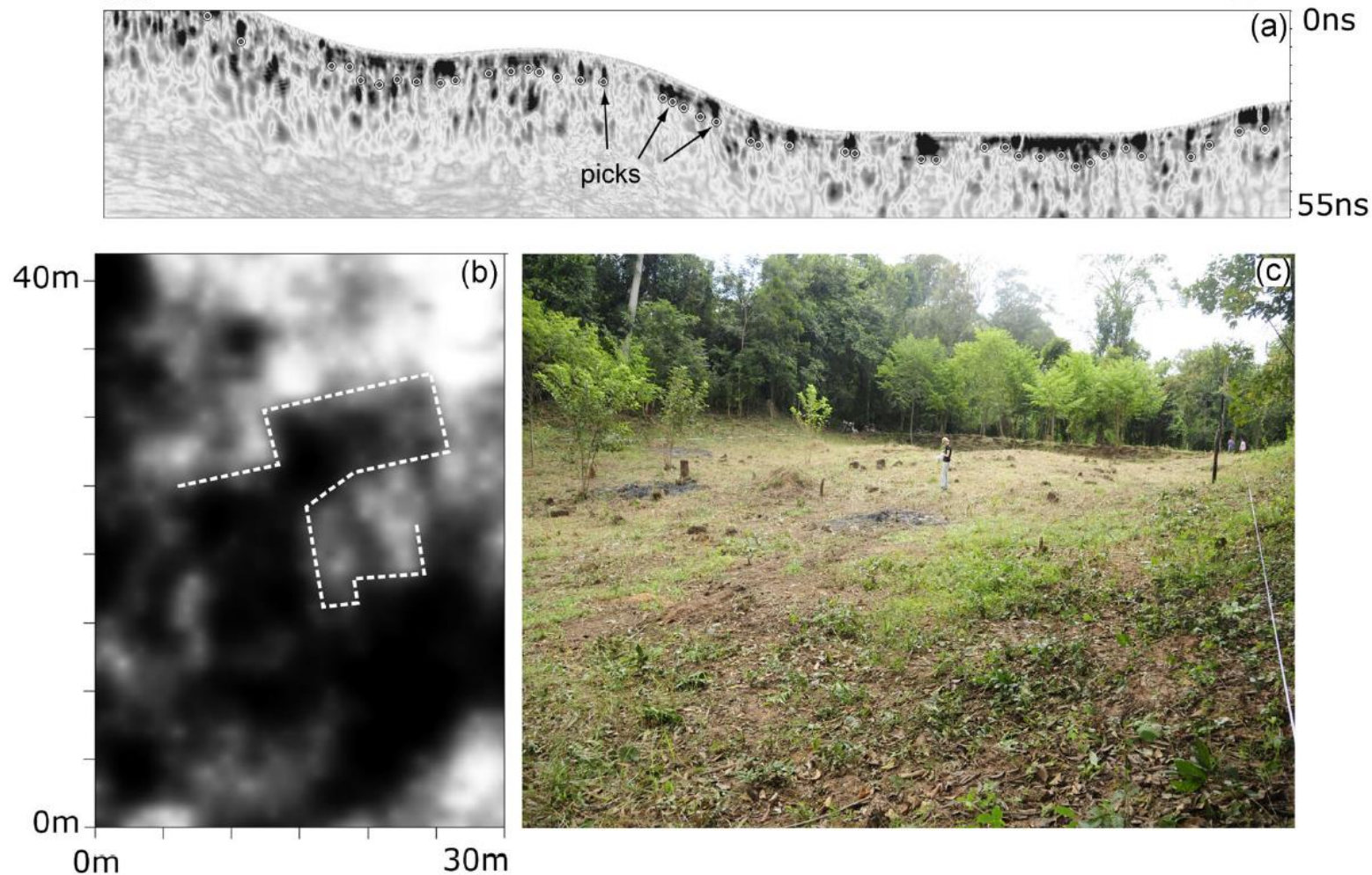

Figure 3. (a) Topographically corrected GPR profile after Hilbert transform showing the interpretation of depth to the laterite surface. The location of this line is shown by a dashed line in Figure 2. (b) GPR slice of $5 \mathrm{~ns}$ thickness ( $16 \mathrm{~cm})$ from $\sim 50 \mathrm{~ns}$ (a depth of $\sim 2.5 \mathrm{~m}$ ) showing a number of geometric features (highlighted with a dotted white line). High amplitude responses are in white and low amplitude responses are in black. This plot covers the same region as the area shown with contours in Figure 2. (c) GPR study area at the chute (defined by measuring tapes) looking south from the northern corner. $G P R$, ground penetrating radar.

\section{Conclusions}

This paper presents the results of investigations of the chute at Koh Ker by excavation, probe, geophysical survey, and hydraulic modeling. We were able to construct a digital elevation model of the laterite pavement forming the chute spillway and make nuanced interpretations about its mode of failure. We were also able to suggest which sections of this spillway had their laterite blocks repurposed to construct a causeway. The detailed profiles of the chute spillway were used to estimate its hydraulic characteristics before and after erosion more accurately than before. This enabled a reworking of the hydrological model, which could help provide more detailed scenarios of the process of failure. The results lend weight to the idea that the dike may have failed during the first or second rainy season after the reservoir had been filled and accords with evidence published by Lustig et al. (2018) that the dike was prone to catastrophic failure in the short term.

This, in turn, has broader implications for understanding the role of Koh Ker in the history of the Angkor period. For now, the role that the dike played in mitigating vulnerability to hydroclimatic variation in the monsoon environment at Koh Ker is poorly understood. What is clear is that the dike was designed to contain the vast majority of Koh Ker's water storage capacity, that the gently sloping terrain makes water retention a technical challenge, and that the dike would have played a key role in provisioning a royal capital including a specialist workforce numbering perhaps in the tens of thousands. Moreover, embarking on projects of civil engineering such as temple building, urban 
renewal, and the development of water infrastructure was central to establishing the legitimacy of Khmer kings (Stern, 1954). It is therefore not difficult to envisage that the failure of the dike at Koh Ker-the largest and most ambitious infrastructural project of the era-may have had a significant impact on the prestige of the sovereign, and contributed to the decision to re-establish Angkor as the capital of the Khmer Empire.

More broadly, our work also highlights the importance of understanding the localized histories of peripheral and regional centers like Koh Ker. What happened here has wider implications for overall urban growth and decline in the Khmer Empire, which cannot be understood from a study of Angkor in isolation. On the one hand, the archaeological record for Koh Ker offers qualified support for the notion that northwest Cambodia-an epicenter of inland agrarian urbanism during the 6 centuries or more of the Khmer Empire-was depopulated at some stage in the 15th century CE. This is consistent with the "urban diaspora" theory and other conventional models of the growth and decline of urban centers across mainland Southeast Asia. On the other hand, the sustainability of a densely populated urban center at Koh Ker appears to have been constrained by much more localized factors, in particular, the inability of engineers to develop technical solutions to water management outside the lowlying floodplain environments that were the traditional heartland of the Khmer. Following the work of Lustig et al. (2018), our study shows that the attempts to adapt traditional floodplain water management strategies to the geography of Koh Ker were prone to rapid failure. This suggests that Koh Ker may have followed a unique historical trajectory with its own specific tempo, and experienced depopulation and urban decline some centuries before-and largely independent from-events in the center of empire at Angkor in the 14th and 15th centuries CE. Even as we can now call into question the architectural, art historical, and the epigraphic case for Koh Ker as an "ephemeral city," the evidence we present here nonetheless helps us to understand the fundamental constraints on the growth of the urban center at its apogee in the 10th century CE.

\section{Acknowledgments}

This work was funded by the Rust Family Foundation, the Graduate Research Support Grant, Graduate and Professional Student Association, the Office of Graduate Education, the Office of the Vice President for Research and Economic Affairs, and the Graduates in Integrative Society and Environmental Research (GISER) Research Seed Fund at Arizona State University. The authors also received financial support from the APSARA National Authority, the University of Sydney, the U.S. National Science Foundation (Dissertation Improvement Grant 1638137), and the European Research Council (ERC) under the European Union's Horizon 2020 research and innovation program (grant agreement No. 639828). Acquisition of the airborne laser scanning data was cosponsored by partners in the Khmer Archaeology Lidar Consortium. Dr. Ian Moffat is the recipient of an Australian Research Council Discovery Early Career Award (\#DE160100703) funded by the Australian Government and a Commonwealth Rutherford Fellowship funded by the Commonwealth Scholarships Commission. Many thanks to Homerton College for hosting lan as a research associate during the writing of this manuscript.

We wish to acknowledge the support of the APSARA National Authority and the National Authority of Preah Vihear and extend our thanks to our outstanding field crews, the staff, and students of the Koh Ker Field Schools, the very supportive residents of the Koh Ker District, and the CMAC. Thank you to Dr. Sarah Sherwood and two anonymous reviewers who provided insightful comments which improved the clarity of this manuscript. 


\section{Data Accessibility}

Data available on request from the authors.

ORCID

lan Moffat http://orcid.org/0000-0002-2171-7145

Sarah Klassen http://orcid.org/0000-0001-5110-713X

Damian Evans http://orcid.org/0000-0003-0320-4319

\section{Bibliography}

Bourdonneau, É. (2011). Nouvelles recherches sur Koh Ker (Chok Gargyar). Jayavarman IV et la maîtrise des mondes. Monuments et Mémoires, 90, 93-141.

Buckley, B. M., Anchukaitis, K. J., Penny, D., Fletcher, R., Cook, E. R., Sano, M., ... Hong, T. M. (2010). Climate as a contributing factor in the demise of Angkor, Cambodia. Proceedings of the National Academy of Sciences USA, 107(15), 6748-6752.

Buckley, B. M., Fletcher, R., Wang, S.-Y. S., Zottoli, B., \& Pottier, C. (2014). Monsoon extremes and society over the past millenium on mainland Southeast Asia. Quaternary Science Reviews, 95, 1-19.

Cassidy, J. Nigel (2009). Ground penetrating radar data processing, modelling and analysis, In Jol, M. Harry. Ground Penetrating Radar: Theory and Applications (pp. 141-176). Amsterdam: Elsevier.

Chambers, J. E., Wilkinson, P. B., Wardrop, D., Hameed, A., Hill, I., Jeffrey, C., ... Gunn, D. A. (2012). Bedrock detection beneath river terrace deposits using three-dimensional electrical resistivity tomography. Geomorphology, 177-178, 17-25.

https://doi.org/10.1016/j.geomorph.2012.03.034

Chanson, H. (2004). The hydraulics of open channel flow: An introduction. Oxford: Elsevier.

Clarke, A. O. (1996). Estimating probable maximum floods in the Upper Santa Ana Basin, Southern California, from stream boulder size. Environmental and Engineering Geoscience, II, 165-182. https://doi.org/10.2113/gseegeosci.II.2.165

Conyers, L. B. (2012). Interpreting ground-penetrating radar for archaeology. New York: Routledge.

Conyers, L. B. (2013). Ground-penetrating radar for archaeology. Maryland: Rowman and Littlefield.

Conyers, L. B. (2016). Ground-penetrating radar for geoarchaeology. London: Wiley-Blackwell.

David, B., Delannoy, J.-J., Gunn, R. G., Brady, L. M., Petchey, F., Mialanes, J., ... Katherine, M. (2017a). Determining the age of a paintings at JSARN-113/23, Jawoyn country, western Arnhem Land. In B. David, P. Tacon, J.-J. Delannoy, \& J.-M. Geneste (Eds.), The Archaeology of Rock Art in Western Arnhem Land, Terra Australis 48 (pp. 371-422). Canberra: ANU Press. https://doi.org/10.22459/TA47.11.2017.14

David, B., Delannoy, J.-J., Gunn, R., Calmin, E., Castets, G., Petchey, F., ... Pietrzak, U. (2017b). Dating painted Panel E1 at Nawarla Gabarnmang, central-western Arnhem Land plateau. In B. David, P. Tacon, J.-J. Delannoy, \& J.-M. Geneste (Eds.), The Archaeology Of Rock Art In Western Arnhem land, Terra Australis 48 (pp. 245-302). Canberra: ANU Press. https://doi.org/10.22459/TA47.11.2017.11 
Diamond, J. M. (2009). Maya, Khmer and Inca. Nature, 461, 479-480.

DIAS, 2010. APHRODITE'S Water Resources (Asian Precipitation - Highly Resolved Observational Data Integration Towards Evaluation of Water Resources): Monsoon Asia Precipitation Data. Available online: http://www.chikyu.ac.jp/precip/ [Accessed 4th November 2013 and 5th April 2017].

Donati, J. C., Sarris, A., Papadopoulos, N., Kalayci, T., Simon, F.-X., Manataki, M., ... Cuenca-Garcia, C. (2017). A regional approach to Greek urban studies through multisettlement geophysical survey. Journal of Field Archaeology, 42(5), 450-467.

Evans, D. (2013). The archaeological landscape of Koh Ker, Northwest Cambodia. Bulletin de l'École Française d'Extrême-Orient, 97/98, 91-150.

Evans, D., Hanus, K., \& Fletcher, R. (2015). The story beneath the canopy: An airborne lidar survey over Angkor, Phnom Kulen and Koh Ker, northwestern Cambodia. In A. Traviglia (Ed.), Across Space and Time. Selected Papers from the 41st Conference on Computer Applications and Quantitative Methods in Archaeology, Perth 25-28 March 2013 (pp. 36-44). Amsterdam: Amsterdam University Press.

Evans, D. H., Fletcher, R. J., Pottier, C., Chevance, J.-B., Soutif, D., Tan, B. S., ... Boornazian, G. (2013). Uncovering archaeological landscapes at Angkor using lidar. Proceedings of the National Academy of Sciences USA, 110(31), 12595-12600.

Fletcher, R., Pottier, C., Evans, D., \& Kummu, M. (2008). The development of the water management system of Angkor: A provisional model. IPPA Bulletin, 28, 57-66.

Goodman, D., Nishimura, Y., \& Rogers, J. D. (1995). GPR time slices in archaeological prospection. Archaeological Prospection, 2, 85-89.

Hall, T., Penny,D., \&Hamilton, R. (2018). Re-evaluating the occupation history of Koh Ker, Cambodia, during the Angkor period: A palaeo-ecological approach. PLoS One, 13, e0203962. https://doi.org/10.1371/journal.pone. 0203962

Horton, R. E. (1907). Weir experiments, coefficients, and formulas. Washington, DC: United States Geological Survey.

Lucero, L., Fletcher, R., \& Coningham, R. (2015). From 'collapse' to urban diaspora: The transformation of low-density, dispersed agrarian urbanism. Antiquity, 89(347), 1139-1154.

Lustig, T. (2012). Linking downstream to upstream in Landscape Archaeology-two southeast Asian examples. In M. L. Bonatz-Tjoa, A. Reinecke, \& D. Bonatz (Eds.), Connecting Empires and States: Selected Papers from the $13^{\text {th }}$ International Conference of the European Association of Southeast Asian Archaeologists (pp. 209-225). Singapore: NUS Press.

Lustig, T., Klassen, S., Evans, D., French, R., \& Moffat, I. (2018). Evidence for the breakdown of an Angkorian hydraulic system, and its historical implications for understanding the Khmer Empire. Journal of Archaeological Science: Reports, 17, 195-211.

Mellett, J. S. (1995). Ground penetrating radar applications in engineering, environmental management, and geology. Journal of Applied Geophysics, 33, 157-166.

Parmentier, H. (1939). L'art khmèr classique: Monuments du quadrant nordest. Paris, Les éditions $d^{\prime}$ 'art et d'histoire.

Penny, D., Hall, T., Evans, D., \& Polkinghorne, M. (2019). Geoarchaeological evidence from Angkor, Cambodia, reveals a gradual decline rather than a catastrophic 15th-century collapse.

Proceedings of the National Academy of Sciences, 116, 4871-4876. 
Sonnemann, T. (2015). Spatial config. of water management at an early Angkorian capitalCombining GPR and TerraSAR-X data to complement an archaeological. map. Archaeological Prospection, 22(2), 105-115. https://doi.org/10.1002/arp.1502

Sonnemann, T., \& Chhay, R. (2014). Nondestructive analysis of threatened Angkorian Ceramic Kilns at Bangkong, Siem Reap, Cambodia. Journal of Indo-Pacific Archaeology, 34, 42-50.

Sonnemann, T., O'Reilly, D., Chhay, R., Pottier, C., \& Fletcher, R. (2015). The buried Towers of Angkor Wat. Antiquity, 89(348), 1420-1438. https://doi.org/10.15184/aqy.2015.179

Stern, P. (1954). Diversité et rythme des fondations royales khmères. Bulletin de l'École Française d'Extrême-Orient, 44(2), 649-685.

USACE (1992). Hydraulic design of spillways. Washington, DC: U.S. Army Corps of Engineers. 